\title{
Water Quality of Major Ponds of Comilla Town
}

\author{
S. Z. K. M. Shamsad, Md. Didar-Ul-Alam*, A. S. M. Shamsuddoha and Mohammad Naushad Alam \\ Department of Soil, Water \& Environment, University of Dhaka.
}

\begin{abstract}
Some important physico-chemical properties of water of major ponds of Comilla Town were studied to evaluate the water quality. Eight water samples were collected during the dry period (March 2005) from eight major ponds of Comilla Town (Ranir dighi, Mandir dighi, Nanuar dighi, Fauzdari dighi, Modina dighi, Dargabari dighi, Darma Sagar and Thakurpara). The result revealed that all the chemical constituents, except a few, are beyond the recommended limit for different uses. Higher value of pH (at Dargabari dighi, Darma Sagar dighi), $\mathrm{OM}$ (at Thakurpara dighi, Fauzdari dighi and Modina dighi), $\mathrm{NH}_{4}{ }^{+}$concentration (at Ranir dighi, Mandir Dighi, Fauzdari dighi, Modina dighi and Dargabari dighi), and lower value of DO (at Fauzdari dighi and Modina dighi) may due to continuous disposal of kitchen wastes, organic wastes, sewage running and fall of twigs as well as extensive used for bathing, washing cloths and utensils etc. All indicate eutrophication and affect community health and hygiene and also create aesthetic problem in the locality.
\end{abstract}

Key words : Ponds, Comilla District, Water quality Eutrophication.

\section{Introduction}

Surface water systems of Bangladesh at present time are polluted by various ways (Shamsad et al., 1999 and Islam, 1999). The sources of surface water pollution are mainly agricultural, industrial and domestic wastes (Dara, 2002 and De, 2000). Polluted water cannot be utilized for drinking, domestic and recreational purposes because of its inherent health risk (Goel, 1997, Davis and Cornwell, 1998). The quality of water interferes with the aesthetic and economic pursuits of water bodies by affecting the fish and other aquatic life (Shamsad et al., 1999 and Islam et al., 2009)

People use surface water for various purposes like domestic, industrial, recreational, aquaculture etc. (WARPO, 2000; Ahmed and Reazuddin, 2000). Pond water in any community is used mainly for domestic supplies, recreations and aquaculture. The quality of pond water is important for long uses because it may affect community health and hygienic, damage aquaculture practices and also created aesthetic problem in the locality (Peavy et al. 1985; Goel, 1997).

The study area, Comilla City is situated in the eastern Bangladesh, located in south of the Gomuti River and about 80-km southeast of capital Dhaka. The location experiences an average rainfall of $2134 \mathrm{~mm} /$ year with average annual temperature maximum $33.20^{\circ} \mathrm{C}$ (BANGLAPEDIA, 2003). It is a populated town and has great historic importance with about 25 ponds in and around the town. These ponds were main sources of water for their multipurpose uses. Earlier, most of the major ponds of this area were very much sustainable in terms of water resources. But, recently these historic water bodies facing serious threat in quality owing to lack of proper management, awareness and connection of sewage drainage run from residential areas to pond etc.

The present research work will ventilate more information about the present water quality of different ponds of Comilla city, which can be used as benchmark data for future surface water resource planning and management of Comilla town.

\section{Materials and methods}

Eight water samples were collected from eight major ponds of the study area during the dry period of March 2005. The sampling was done very cautiously using spot sampling techniques (Gupta, 2005). The high density PVC bottles were used for sampling. They were thoroughly cleaned by rinsing with $8 \mathrm{~N} \mathrm{HNO}_{3}$ and deionized water followed by repeated washing with water sampled so as to avoid contamination (De, 2000). The bottles were kept air tight and labeled properly for identification and some parameters such as $\mathrm{pH}$, Electrical Conductivity (EC), Dissolved Oxygen (DO) and temperature of the samples were measured on the spot using glass electrode $\mathrm{pH}$ meter, EC meter, DO meter

\footnotetext{
* Corresponding author: E-mail: dilafi@gmail.com or fiza_lamia@yahoo.ca
} 
and Thermometer respectively (Gupta, 2005, De, 2000, and Peavy et al., 1985). Aeration during sampling was avoided as best as possible. A portion of the water samples were acidified for some specific analysis.

The physico-chemical analysis was carried out in the advanced analytical laboratory of the Department of Soil, Water and Environment, University of Dhaka, following the established analytical methods (Jackson, 1967; Huq and Alam, 2005; De, 2000 and Page, 1982). The threshold odour number (TON) of water samples was calculated as per Peavy et al., (1985).

Organic carbon (OC) content was estimated by Walkey and Black's wet oxidation and multiplied by 1.724 to get organic matter (OM) content as described by Jackson, (1967). A total dissolved solids (TDS) was determined by gravimetrically (Mishra and Ahmed, 1987). Nitrate $\left(\mathrm{NO}_{3}{ }^{-}\right)$content was determined by Micro Kjeldahl's distillation (Jackson, 1967), Phosphate $\left(\mathrm{PO}_{4}{ }^{3-}\right)$, Sulphate $\left(\mathrm{SO}_{4}{ }^{2-}\right)$, and Boron (B) by visible Spectrophotometry method, Chloride $\left(\mathrm{Cl}^{-}\right)$and Bicarbonate $\left(\mathrm{HCO}_{3}{ }^{-}\right)$by titration and Calcium $\left(\mathrm{Ca}^{2+}\right)$ and $\mathrm{Mg}\left(\mathrm{Mg}^{2+}\right)$ by EDTA complexometry method (Page, 1982), Sodium $\left(\mathrm{Na}^{+}\right)$and Potassium $\left(\mathrm{K}^{+}\right)$by Flame Photometry (Jackson,1967). Total iron determined by Phenanthrolin method and Manganese $\left(\mathrm{Mn}^{2+}\right)$ by Persulphate method (De, 2000).

\section{Results and Discussion}

The physico-chemical parameters of the water samples of the study area of Comilla Town are presented in the Table I, Table IIa and Table IIb.
Table I reveals that the temperature range is $17^{\mathrm{O}} \mathrm{C}$ and $21^{\mathrm{O}} \mathrm{C}$, whereas $\mathrm{pH}$ values varied from 5.8 to 8.9, which are within the permissible limit for diverse uses (Dara, 2002, DOE, 1997; and UCCC, 1974). But owing to higher $\mathrm{pH}$ value, water of Dharma Sagar and Dargabari pond is not suitable for irrigation, domestic and recreational uses (Dara, 2002, DOE, 1997; and UCCC, 1974). The higher $\mathrm{pH}$ values in Dharma Sagar and Dargabari pond may be due to excessive use for bathing and washing using alkaline soap. Peoples of this locality extensively use these ponds for bathing, washing of cloths and utensils. In the study area, the EC values of pond water varied from 0.27 to $0.62 \mathrm{dSm}^{-1}$.

It can be seen from the Table I that the values of TON beyond the acceptable limit as recorded in Fauzdari dighi (4.1), Madina dighi (4.4), and Thakur para (4.0). These ponds were also usually seen dirty.

High organic matter value in Fauzdari dighi, Madina Mosque pond, and Thakurpara pond indicates deposition of organic waste from sewage, fall of twigs, various kitchen wastes dumped into the pond side etc. All these wastes undergo degradation and decomposition by bacterial activity in presence of dissolved oxygen (DO). This results in rapid depletion of DO level from the water, which is harmful to aquatic life. The optimum DO level in natural water is 4 $\mathrm{mgL}^{-1}$ to $6 \mathrm{mgL}^{-1}$, which is essential for supporting aquatic lives (Dara, 1997, Weiner, 2000). Most aquatic organisms cannot survive below this range in water. Table I shows that the DO value of Fauzdari and Madina Mosque ponds is lower than the optimum DO value and which may be due to high organic matter. When OM value is high, biochemical Oxygen Demand (BOD) is also high. BOD is the quantity of oxygen required by bacteria and other microorganisms dur-

Table I. Physico-chemical parameters of water samples of major ponds of Comilla Town

\begin{tabular}{|c|c|c|c|c|c|c|c|c|c|}
\hline \multirow[t]{3}{*}{ Name of ponds } & \multicolumn{9}{|c|}{ Parameters } \\
\hline & \multirow{2}{*}{$\begin{array}{l}\text { Temp. } \\
{ }^{\mathrm{O}} \mathrm{C}\end{array}$} & \multirow[t]{2}{*}{$\mathrm{pH}$} & \multirow{2}{*}{$\begin{array}{c}\mathrm{EC} \\
\mathrm{dSm}^{-1}\end{array}$} & DO & BOD & TSS & TDS & $\mathrm{OM}$ & Odour \\
\hline & & & & & \multicolumn{3}{|c|}{$\mathrm{mgL}^{-1}$} & $\%$ & TON \\
\hline Ranir dighi & 20 & 5.9 & 0.32 & 4.20 & 34.07 & 106.21 & 16 & 0.38 & 2.7 \\
\hline Mandir dighi & 19 & 6.0 & 0.51 & 5.12 & 48.76 & 99.02 & 25 & 0.44 & 3.0 \\
\hline Nanuar dighi & 19 & 5.9 & 0.31 & 6.43 & 42.69 & 87.75 & 16 & 0.50 & 2.1 \\
\hline Fauzdari dighi & 18 & 7.9 & 0.38 & 3.95 & 65.90 & 110.12 & 17 & 0.95 & 4.1 \\
\hline Modina dighi & 21 & 5.8 & 0.56 & 3.91 & 60.15 & 107.38 & 21 & 0.93 & 4.4 \\
\hline Dargabari dighi & 19 & 8.0 & 0.45 & 4.35 & 39.26 & 85.23 & 18 & 0.46 & 2.8 \\
\hline Darma Sagar & 17 & 8.9 & 0.27 & 7.95 & 35.09 & 96.11 & 20 & 0.27 & 2.5 \\
\hline Thakurpara & 19 & 7.4 & 0.62 & 5.17 & 63.11 & 79.13 & 27 & 0.82 & 4.0 \\
\hline
\end{tabular}


Table IIa. Anions concentration of water samples of major ponds of Comilla Town.

\begin{tabular}{l|c|c|c|c|c}
\hline \multirow{2}{*}{$\begin{array}{l}\text { Name of } \\
\text { ponds }\end{array}$} & \multicolumn{5}{|c}{ Parameters (Conc. in $\mathrm{mgL}^{-1}$ ) } \\
\cline { 2 - 6 } $\mathrm{HCO}_{3}{ }^{-}$ & $\mathrm{NO}_{3}{ }^{-}+\mathrm{NO}_{2}^{-}$ & $\mathrm{Cl}^{-}$ & $\mathrm{PO}_{4}{ }^{-}$ & $\mathrm{SO}_{4}{ }^{2-}$ \\
\hline Ranir dighi & 25.05 & 15.98 & 0.03 & 2.32 & 4.1 \\
Mandir dighi & 33.21 & 28.07 & 0.05 & 2.39 & 5.2 \\
Nanuar dighi & 39.39 & 18.55 & 0.04 & 1.28 & 2.3 \\
Fauzdari dighi & 34.51 & 12.86 & 0.08 & 4.19 & 5.1 \\
Modina dighi & 21.92 & 21.25 & 0.09 & 3.83 & 5.9 \\
Dargabari dighi & 42.28 & 10.32 & 0.07 & 2.75 & 4.1 \\
Darma Sagar & 16.76 & 26.62 & 0.02 & 1.26 & 2.0 \\
Thakurpara & 41.69 & 43.24 & 0.02 & 2.56 & 2.3 \\
\hline
\end{tabular}

Nanuar dighi, Fauzdari dighi, Thakurpara and Madina Mosque pond were restricted higher alkalinity. Higher alkalinity in this area may attributes to higher use of soap, detergent etc. for bathing, cloths washing and cleaning of various domestic appliances (Table IIa).

The average $\mathrm{NO}_{3}{ }^{-}+\mathrm{NO}_{2}{ }^{-}$concentration in the water samples from different ponds of the study area ranged from 5.46 to $16.38 \mathrm{mgL}^{-1}$ (Table IIa), which beyond the recommendation limit of $5 \mathrm{mgL}^{-1}$ (UCCC, 1974). The $\mathrm{NO}_{3}{ }^{-}+\mathrm{NO}_{2}{ }^{-}$concentration of Thakurpara pond, Nanuar pond and Dargabari pond is in alarming stage and indicate eutrophication, which may due to continuous discharge of domestic waste.

Table IIb. Cations concentration of water samples of major ponds of Comilla Town.

\begin{tabular}{l|c|c|c|c|c|c|c|c|c}
\hline Name of ponds & \multicolumn{10}{c}{ Parameters (Conc in $\mathrm{mgL}^{-1}$ ) } \\
\cline { 2 - 10 } & $\mathrm{Pb}^{+}$ & $\mathrm{Na}^{+}$ & $\mathrm{K}^{+}$ & $\mathrm{Ca}^{2+}$ & $\mathrm{Mg}^{2+}$ & $\mathrm{Fe}^{3+}$ & $\mathrm{Zn}^{2+}$ & $\mathrm{B}^{3+}$ & $\mathrm{NH}_{4}^{+}$ \\
\hline Ranir dighi & 3.23 & 3.23 & 13.2 & 25.05 & 15.98 & 0.03 & 2.32 & 1.18 & 4.1 \\
Mandir dighi & 3.35 & 3.35 & 12.32 & 33.21 & 28.07 & 0.05 & 2.39 & 1.21 & 5.2 \\
Nanuar dighi & 4.18 & 4.18 & 7.59 & 39.39 & 18.55 & 0.04 & 1.28 & 0.3 & 2.3 \\
Fauzdari dighi & 7.2 & 7.2 & 16.56 & 34.51 & 12.86 & 0.08 & 4.19 & 0.98 & 5.1 \\
Modina dighi & 4.98 & 4.98 & 18.82 & 21.92 & 21.25 & 0.09 & 3.83 & 1.56 & 5.9 \\
Dargabari dighi & 2.18 & 2.18 & 10.24 & 42.28 & 10.32 & 0.07 & 2.75 & 0.83 & 4.1 \\
Darma Sagar & 1.46 & 1.46 & 7.78 & 16.76 & 26.62 & 0.02 & 1.26 & 0.75 & 2.0 \\
Thakurpara & 2.12 & 2.12 & 11.62 & 41.69 & 43.24 & 0.02 & 2.56 & 0.72 & 2.3 \\
\hline
\end{tabular}

ing the biochemical degradation and transformation of organic matter present in wastewater under aerobic conditions (Dara, 2002). The total dissolved solid (TDS) values of the studied ponds ranged from 16 to $27 \mathrm{mgL}^{-1}$, which are well below the standard limit $250 \mathrm{mgL}^{-1}$ (Peavy et al., 1985; Davis and Cornwell, 1988) and can be used for domestic supplies, recreational purposes. According to standard TDS value for drinking $\left(250 \mathrm{mgL}^{-1}\right)$ and irrigation water (0 to $2000 \mathrm{mgL}^{-1}$ ), all ponds water can be used for diverse purposes.

The total suspended solid (TSS) values of the study ponds ranges from 79 to $110 \mathrm{mgL}^{-1}$. High TSS in these ponds may be due to the dumping of different domestic wastes as macro pollutants from the surrounding city dwellers. High TSS present in water bodies may block the sunlight required to photosynthesis by the bottom vegetation (Peavy et.al., 1985; Davis and Cornwell, 1998).

The alkalinity of most water caused by dissolved carbonate $\left(\mathrm{CO}_{3}{ }^{-2}\right)$ and bicarbonate $\left(\mathrm{HCO}_{3}{ }^{-}\right)$salts (Gupta, 2005; Peavy et.al., 1985). In the present study water body of Ranir dighi,
The average $\mathrm{NH}_{4}{ }^{+}$concentration in the water samples from different ponds of the study area ranged from 2.0 - 5.9 $\mathrm{mgL}^{-1}$ (Table IIb), were higher than recommendation limit of $1.5 \mathrm{mgL}^{-1}$ (UCCC, 1974). The $\mathrm{NH}_{4}{ }^{+}$concentration of Ranir dighi, Mandir Dighi, Fauzdari dighi, Modina dighi and Dargabari dighi is in alarming stage and indicate eutrophication, which may due to the discharge of domestic waste.

The safe limit for Sulphate $\left(\mathrm{SO}_{4}{ }^{2-}\right)$ concentration in all purposes is $<200 \mathrm{mgL}^{-1}$ (WHO, 1998). Fauzdari pond got the highest $\mathrm{SO}_{4}{ }^{2-}$ concentration of $5.58 \mathrm{mgL}^{-1}$. All the Chloride $\left(\mathrm{Cl}^{-}\right)$values are within the permissible limits of $200 \mathrm{mgL}^{-1}$ (Gupta, 2005). The phosphate $\left(\mathrm{PO}_{4}{ }^{3-}\right)$ concentration in the water of the study area varied from 1.26 to $4.19 \mathrm{mgL}^{-1}$ (Table IIa). The phosphate value in the pond water of Thakurpara and Nanuar dighi indicates higher phosphate pollution (Davis and Cornwell, 1988, Rittes and Shirmohammadi, 2001). The increase in nutrients of water can cause spurt in algal productivity i.e.; eutrophication. Bird droppings, natural run-off, fall of leaves and twigs from surrounding vegetation, continuous discharge of domestic 
waste water, bathing, washing are principal sources of $\mathrm{N}, \mathrm{P}$, $\mathrm{K}$ in the pond water of the study area. The concentrations of iron in the water of the study area are varied from 0.02 to $0.09 \mathrm{mgL}^{-1}$ (Table II).

Water color of the Madina mosque pond, Fauzdari pond, Ranir dighi etc. is objectionable but in case of Madina mosque it is nearly olive green and indicates eutrophication.

The alkalinity hazards involved in the increase of anionic radicals as $\mathrm{CO}_{2}{ }^{-2}, \mathrm{HCO}_{3}{ }^{-}, \mathrm{PO}_{4}{ }^{3-}$ etc., which acts on a buffer controlling $\mathrm{pH}$ fluctuation in water body. It is one of the important water quality parameter and may cause eye irritation in humans and chlorosis in plants. Surface waters with alkalinity less than 200 meqL $^{-1}$ are potentially sensitive to heavy acid deposition (Kannan, 1997).

The coefficient of correlation analysis among physicochemical properties (Table IIIa) indicated that the EC and TDS as well as the BOD and OM had significant positive contribution to pollute the water. On the contrary, the coefficient of correlation analysis among cations (Table IIIa) indicated that

Table IIIa. Correlations between physiochemical properties of the water samples.

\begin{tabular}{lccccccc}
\hline Parameters & $\mathrm{pH}$ & $\mathrm{EC}$ & $\mathrm{DO}$ & $\mathrm{BOD}$ & $\mathrm{TSS}$ & TDS & OM \\
\hline $\mathrm{pH}$ & 1 & -0.217 & 0.381 & -0.047 & -0.240 & 0.020 & -0.110 \\
EC & & 1 & -0.485 & 0.668 & -0.250 & $0.780^{*}$ & 0.592 \\
DO & & 1 & -0.462 & -0.379 & 0.064 & -0.591 \\
BOD & & & 1 & 0.127 & 0.436 & $0.946^{* *}$ \\
TSS & & & & 1 & -0.364 & 0.216 \\
TDS & & & & & 1 & 0.206 \\
OM & & & & & & & 1 \\
\hline
\end{tabular}

*Correlation is significant at the 0.05 level, **Correlation is significant at the 0.01 level

Table IIIb. Correlations between cations the water samples

\begin{tabular}{lcccccccc}
\hline Cations & $\mathrm{Na}^{+}$ & $\mathrm{K}^{+}$ & $\mathrm{Ca}^{2+}$ & $\mathrm{Mg}^{2+}$ & $\mathrm{Fe}^{3+}$ & $\mathrm{Zn}^{2+}$ & $\mathrm{B}^{3+}$ & $\mathrm{Pb}^{2+}$ \\
\hline $\mathrm{Na}^{+}$ & 1 & .680 & .043 & -.437 & .691 & .697 & .274 & .364 \\
$\mathrm{~K}^{+}$ & & 1 & -.208 & -.152 & $.708^{*}$ & $.915^{* *}$ & $.823^{*}$ & .615 \\
$\mathrm{Ca}^{2+}$ & & & 1 & .034 & .060 & .072 & -.490 & .464 \\
$\mathrm{Mg}^{2+}$ & & & & 1 & -.576 & -.249 & -.096 & .392 \\
$\mathrm{Fe}^{3+}$ & & & & & 1 & $.799^{*}$ & .517 & .373 \\
$\mathrm{Zn}^{2+}$ & & & & & & 1 & .639 & .675 \\
$\mathrm{~B}^{3+}$ & & & & & & & 1 & .306 \\
$\mathrm{~Pb}^{2+}$ & & & & & & & & 1 \\
\hline
\end{tabular}

${ }^{*}$ Correlation is significant at the 0.05 level, ${ }^{* *}$ Correlation is significant at the 0.01 level

Table IIIc. Correlations between anions of collected water samples.

\begin{tabular}{lcccccc}
\hline Anions & $\mathrm{CO}_{3}{ }^{2-}$ & $\mathrm{HCO}_{3}{ }^{-}$ & $\mathrm{NO}_{3}{ }^{-}+\mathrm{NO}_{2}{ }^{-}$ & $\mathrm{Cl}^{-}$ & $\mathrm{PO}_{4}{ }^{3-}$ & $\mathrm{SO}_{4}{ }^{2-}$ \\
\hline Carbonate & 1 & -.364 & .536 & $.912 * *$ & .460 & -.682 \\
Bicarbonate & & 1 & .469 & -.253 & .609 & .063 \\
Nitrate & & & .456 & $.952^{* *}$ & -.554 \\
Chloride & & & 1 & .495 & -.651 \\
Phosphate & & & & 1 & -.561 \\
Sulphate & & & & & 1 \\
\hline
\end{tabular}

**Correlation is significant at the 0.01 level (2-tailed). 
there was a significant positive interaction between Fe and $\mathrm{Zn}$ in case of water quality deterioration, where as among anions (Table IIIc) there were a significant positive interactions between $\mathrm{CO}_{3}{ }^{-2}$ and $\mathrm{Cl}^{-}$as well as $\mathrm{NO}_{3}{ }^{-}$and $\mathrm{PO}_{4}{ }^{3-}$ indicated that the higher alteration in water quality of the study areas.

\section{Conclusion}

The present study shows that the surface water of the study area becomes contaminated and polluted due to excessive use of these ponds for bathing, washing using alkaline soap, connection of sewage drainage run from residential areas etc. This imparts a negative impact on the Town dwellers. If the present scale of indiscriminate and continuous waste disposal and unplanned uses keep going on in the study areas, the water quality will turn into a toxic and poisonous in the long run. The historic recreational value of the major ponds will remain under threat until and unless there exists a sound and planned uses and waste disposal system in the areas.

\section{References}

Ahmed, A. U. and Reazuddin. (2000) Industrial Pollution of water systems in Bangladesh. (University Press Limited, Dhaka, Bangladesh), pp 175-178.

BANGLAPEDIA. (2003) National Encyclopedia of Bangladesh. Asiatic Society of Bangladesh, ISBN-98432-0583-9, Comilla District, 3: 71-75.

BBS. (1996) Statistical Yearbook of Bangladesh Bureau of Statistics, Statistics Division, Ministry of Planning, People's Republic of Bangladesh, pp 10.

Dara S. S. (2002) A Text Book of Environmental Chemistry and Pollution Control. (S. Chand and Company Limited, New Delhi), pp 24-30.

Davis M. L. and Cornwell D. A. (1998) Introduction to Environmental Engineering. (WCB/McGraw-Hill Book Co., Singapore), pp 469-535.

De A. K. (2000) Environmental Chemistry. 4th Ed. (New Age International (Pvt.) Ltd., New Delhi), pp 2-4.

DoE (1997) Bangladesh Gazette, No. DA-1, Department of Environment, Ministry of Environment and Forest, pp 1324-1327.

Goel P. K. (1997) Water Pollution: Causes, Effect and
Control. (New Age Int. (Pvt.) Limited, New Delhi), pp 97-115.

Gupta P. K. (2005) Metods in Environmental Analysis: water, soil and air. ( Agrobios India, Jodhpur), pp 1373.

Huq I. S. M. and Alam M. D. (2005) A text Book on Analyses of Soil, Plant and Water. (BangladeshAustralia Centre for Environmental Research (BACER-DU). University of Dhaka, Bangladesh), pp xxii-246.

Islam M. S., Mahmud M. S., Chowdhury N. and Shamsad S. Z. K. M. (2009) Water and sediment anality of Fay"s Lake, Chittagong, Dhaka Univ. J. Bio. Sci. 18(2):147158.

Jackson M. L. (1967) Soil Chemical Analysis. (Prentice Hall Inc. Englewood Cliffs, N. J., USA), pp 1-498.

Kannan K. (1997) Fundamentals of Environmental Pollution.(S. Chand and Compant Limited. New Delhi), pp 142-183.

Michael A. M. (1992) Irrigation Theory and Practices (Vikash Publishing House Limited. New Delhi), pp 740 .

Mishra R. D.and Ahmed, M. (1987) Manual of Irrigation Agronomy. (Oxford and IBH publishing Co. Pvt. Limited, New Delhi), pp 248-271.

Page A. L. (1982) Methods of Soil Analysis. Part 2. (Am. Soc. Agrog. Soil Sci. Sc. Am. Wis. USA), pp 159-446.

Peavey H. S., Rowe D. R. R. and Tehobanoglous G. (1985) Environmental Engineering. (McGraw-Hill Book Company, NY, USA), pp 417-461.

Ritter W. F. and Shirmohammadi, A. (2001) Agricultural Nonpoint Source Pollution. (Lewis Publishers, Boca Raton, USA), pp 91 - 110.

Shamsad S. Z. K. M. and Islam, M. S. (1999) Heavy metal pollution in surface water in and around the industrial areas of Dhaka city. J. Asiat. Soc. Bangaldesh, Sci. 25(2): 299 - 308.

Shamsad S. Z. K. M., Khan M. B. R and Islam M.S. (1999) Quality of Surface Water of southeastern outskirt of 
Dhaka city for irrigation purposes, Bangladesh $\mathrm{J}$. Agril. Res. 24(4): 541 - 548.

UCCC. (1974) Guidelines for Interpretations of Water Quality for Irrigation. Technical Bulletin, University of California Committee of Consultants, California, USA, pp. 20-28.

USDHEW. (1962) Drinking Water Standards, PHS Bulletin No. 956. U.S. Department of Health, Education and Welfare, Washington D. C. USA.

WARPO. (2000) Environment, National Water Management Plan Project, Water Resources Planning Organization, Ministry of Water Resource, Government of Bangladesh. Annex G.
Weiner E. R. (2000) Applications of Environmental Chemistry. (Lewis Publishers, Boca Raton, USA), pp 14-67.

WHO. (1998) Guidelines for Drinking-water quality and recommendations. 2nd Ed. World Health Organization, Geneva, Vol-1.

Zimmy H. (1984) Ecological Effects of Industrial Pollutants and their effects on Ccultivated Plants. In: Chemistry for Protection of the Environment (Ed.), Elsevier, Amsterdam, pp 79-91.

Received : August 31, 2008;

Accepted : July 27, 2009 